inz. Roman Makowski

mgr inz. Jerzy Frączek

Instytut Pojazdów Szynowych ,TABOR”

\title{
Metrologia - podstawowe instytucje, normy prawne i zasady dzialania
}

\begin{abstract}
$W$ artykule przedstawiono aktualnie obowiqzujace $w$ Polsce akty prawne oraz ich powiazania z prawem unijnym. Wymieniono organizacje międzynarodowe zajmujace się metrologia a także zaprezentowano wzajemne relacje między nimi oraz krótki rys historyczny.

$W$ pierwszej części zostały przywołane i omówione podstawowe akty prawne zwiqzane $z$ metrologia prawna, natomiast $w$ drugiej przedstawiono światowe organizacje funkcjonujace $w$ metrologii naukowej oraz ich strukture organizacyjnq.
\end{abstract}

\section{Wstęp}

Wspólny rynek europejski wymaga ujednolicenia większości przepisów tak, aby były one spójne na całym obszarze Unii Europejskiej. Odbywa się to poprzez dyrektywy, które nakładają na państwa członkowskie obowiązek wydania $\mathrm{w}$ określonym terminie własnych przepisów wprowadzających w życie dyrektywy.

W Unii Europejskiej po 1985 roku wprowadzono tzw. „Nowe Podejście” w celu harmonizacji przepisów technicznych, które ułatwiają i przyspieszają ujednolicanie różnorodnych krajowych uregulowań w dziedzinie bezpieczeństwa wyrobów przemysłowych. Dyrektywy zawierają tylko zasadnicze wymagania związane $\mathrm{z}$ bezpieczeństwem, zdrowiem, ochroną użytkownika i ochroną środowiska. Pozostałe szczegóły techniczne zawarte są w odpowiednich zharmonizowanych normach europejskich (EN).

Przyrządy pomiarowe wprowadzane do użytkowania w państwach członkowskich Unii Europejskiej zgodnie z dyrektywami powinny spełniać odpowiednie wymagania metrologiczne.

W celu spełnienia wymagań unijnych konieczny jest właściwy nadzór metrologiczny.

Wyposażenie pomiarowe stosowane do wzorcowań, badań i inspekcji metrologicznej ma bardzo istotny wpływ na wyniki pomiarów. Na szczeblu krajowym musi być nadzorowane przez krajową instytucję metrologiczną w Polsce Główny Urząd Miar. Wyposażenie to może być utrzymywane jako wzorcowe różnego poziomu lub użytkowe.

Nadzór metrologiczny nad wyposażeniem pomiarowym może być realizowany w ramach struktury metrologii prawnej lub w strukturach dobrowolnego nadzoru metrologicznego, czyli metrologii naukowej.

Poniżej na rys.1 przedstawiono różnice pomiędzy metrologią prawną a metrologią naukową, które są oparte na wymaganiach powszechnie znanych dla każdej z wymienionych metrologii.
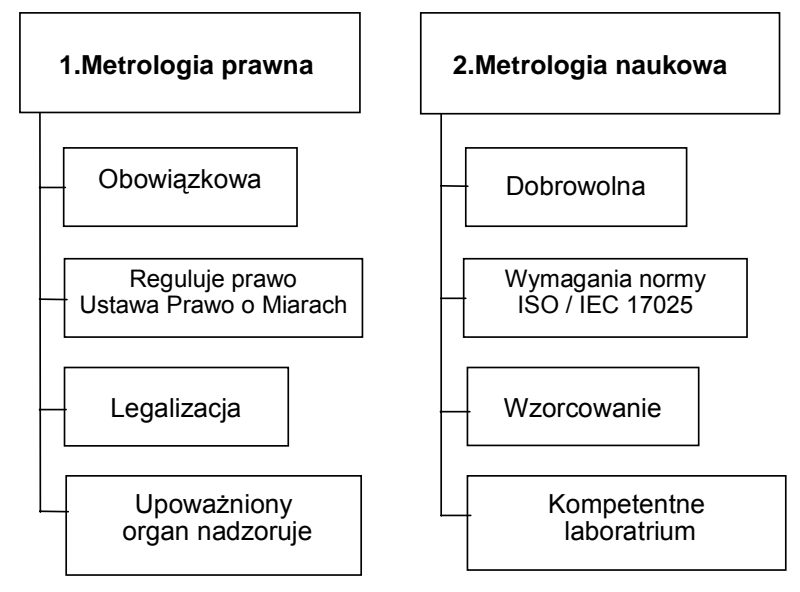

Rys. 1. Struktura nadzoru metrologicznego w Polsce

W dalszej części artykułu zostaną omówione poszczególne punkty nadzoru metrologicznego, w zależności od tego, w którym sposobie nadzoru występują.

2. Metrologia prawna

2.1. Wprowadzenie

Rozwój handlu, usług i innych dziedzin wymusił powstanie metrologii prawnej, której celem jest zapewnienie rzetelności wykonywanych pomiarów w tych dziedzinach.

Według definicji podanej w Międzynarodowym Słowniku Terminów [8] metrologia prawna jest działem odnoszącym się do postępowania, które wynika z wymagań ustawowych i dotyczy pomiarów, jednostek miar, przyrządów pomiarowych oraz metod pomiarowych, które przeprowadzane są przez kompetentne organy. Zasadniczym zadaniem metrologii prawnej jest zapewnienie jednolitości pomiarów.

Czynności wykonywane przez organy państwowej służby metrologii prawnej i inne organy do 
tego uprawnione polegają na stwierdzeniu i zaświadczeniu, że narzędzie pomiarowe spełnia wymagania przepisów legalizacyjnych (obejmuje sprawdzenie, cechowanie narzędzi pomiarowych i wydanie świadectwa legalizacyjnego).

Początkiem polskiej metrologii prawnej był „Dekret o miarach” z 8.02.1919, który ukazał się w Dzienniku Praw Państwa Polskiego nr 15, poz. 211.

W dekrecie tym uregulowano następujące zagadnienia:

- określono legalne jednostki miar tj. długości, powierzchni, objętości, kąta płaskiego, masy i temperatury

- zdefiniowano pojęcia wzorca masy, uchybień, legalizacji

- wprowadzono obowiązek stosowania w obrocie publicznym legalnych jednostek miar i przyrządów legalizowanych

- określono zadania i organizację Głównego Urzędu Miar

- $\quad$ wprowadzono kary za przekroczenie dekretu o miarach.

2.2. Aktualnie obowiązujące akty prawne w Polsce.

Najważniejszym aktem prawnym w zakresie nadzoru metrologicznego jest „Prawo o Miarach”, zawarte w ustawie z dnia 11 maja 2001 r. Prawo o miarach, tekst jednolity Dz.U. 2013 poz. 1069 [1].

Prawo to obejmuje w swej zawartości takie działy jak:

- przepisy ogólne

- legalne jednostki miar i państwowe wzorce jednostek miar

- prawna kontrola metrologiczna

- kompetencje i zadania organów administracji miar

- nadzór nad wykonywaniem przepisów ustawy

- sankcje za naruszenie przepisów ustawy

- przepisy dostosowujące, przejściowe i końcowe.

Ponadto w ramach nadzoru metrologicznego aktualnie obowiązują następujące akty prawne:

- Ustawa z dnia 30 sierpnia 2002 r. o systemie oceny zgodności [2]

- Rozporządzenie Ministra Gospodarki z dnia 18 grudnia 2006 r. w sprawie zasadniczych wymagań dla przyrządów pomiarowych [3]

- Rozporządzenie Ministra Gospodarki z dnia 27 grudnia 2007 r. w sprawie rodzajów przyrządów pomiarowych podlegających prawnej kontroli metrologicznej oraz zakresu tej kontroli [4]

- Rozporządzenie Ministra Gospodarki z dnia 7 stycznia 2008 r. w sprawie prawnej kontroli metrologicznej przyrządów pomiarowych [5].

Poza wymienionymi aktami prawnymi obowiązują jeszcze inne przepisy wykonawcze dotyczące wymagań, którym powinny odpowiadać poszczególne rodzaje przyrządów pomiarowych, podlegające prawnej kontroli metrologicznej.

\subsection{Prawna kontrola metrologiczna urządzeń po-} miarowych

Dział metrologiczny odnosi się do działań, które wynikają z wymagań ustawowych i dotyczą pomiarów, jednostek miar, przyrządów pomiarowych i metod pomiarowych, i które przeprowadzane są przez kompetentne organy. Kompetentne organy odpowiedzialne za działanie metrologii prawnej lub za część tych działań, są zwykle nazywane służbami metrologii prawnej. W Polsce w celu zapewnienia rzetelności wykonywanych pomiarów w handlu, służbie zdrowia, przy opłatach i innych ważnych dziedzinach działalności człowieka metrologia prawna jest obowiązkowa.

Prawnej kontroli metrologicznej w oparciu o przepisy wydane na podstawie art.8 ustawy [1] podlegaja przyrządy pomiarowe stosowane:

- w ochronie zdrowia, życia i środowiska

- w ochronie bezpieczeństwa i porządku publicznego

- w ochronie praw konsumenta

- przy pobieraniu opłat, podatków i innych należności budżetowych oraz ustalaniu opustów, kar umownych, wynagrodzeń i odszkodowań a także przy pobieraniu i ustalaniu podobnych należności i świadczeń

- przy dokonywaniu kontroli celnej

- w obrocie handlowym.

Ustawa nakłada obowiązek wykonania prawnej kontroli metrologicznej każdego przyrządu pomiarowego stosowanego do ww. pomiarów i powinna obejmować:

- zatwierdzenie typu i legalizację pierwotną albo legalizację jednostkową oraz legalizację ponowną

- zatwierdzenie typu oraz legalizację jednostkową

- wyłącznie zatwierdzenie typu

- legalizację pierwotną albo legalizację jednostkową i legalizację ponowną.

Wymagania dotyczące przeprowadzenia kontroli metrologicznej zawarte są w Rozporządzeniu Ministra Gospodarki z dnia 7 stycznia 2008r. [5] gdzie określono:

- tryb zgłaszania przyrządów pomiarowych do prawnej kontroli metrologicznej

- szczegółowy sposób przeprowadzania prawnej kontroli metrologicznej przyrządów pomiarowych

- dowody legalizacji wydawane dla określonych rodzajów przyrządów pomiarowych

- okresy ważności legalizacji określonych rodzajów przyrządów pomiarowych oraz terminy zgłaszania do legalizacji ponownej przyrządów pomiarowych wprowadzonych do obrotu lub użytkowanych po dokonaniu oceny zgodności

- wzory znaków zatwierdzenia typu, cech legalizacji i cech zabezpieczeniowych. 


\subsection{Potwierdzenie metrologiczne metrologii praw-} nej - legalizacja

Potwierdzenie metrologiczne jest to zbiór operacji wymaganych do zapewnienia zgodności wyposażenia pomiarowego z wymaganiami wynikającymi z jego zamierzonego zastosowania.

Terminologię oraz organizację związaną $\mathrm{z}$ legalizacją wykonywaną przez organy administracji miar przedstawiono poniżej.

Legalizacja - jest to zespół czynności obejmujących sprawdzenie i poświadczenie dowodem legalizacji, że przyrząd pomiarowy spełnia wymagania i jest czynnością

urzędową obowiązkową wynikającą z prawa.

Legalizacja pierwotna - wykonywana jest na wniosek użytkownika lub wykonawcy naprawy przed wprowadzeniem danego egzemplarza przyrządu do obrotu lub użytkowania.

Legalizacja jednostkowa - legalizacja pierwotna przyrządu pomiarowego $\mathrm{w}$ wykonaniu jednostkowym, (skonstruowanego dla określonego, szczególnego zastosowania), wykonywana na wniosek użytkownika lub wykonawcy naprawy.

Legalizacja ponowna - wykonywana jest na wniosek użytkownika lub wykonawcy naprawy $\mathrm{w}$ stosunku do przyrządów pomiarowych wprowadzonych do obrotu lub użytkowania. Wykonywana jest na wniosek użytkownika lub wykonawcy naprawy.

Badanie typu - to zespół czynności mających na celu wykazanie, czy przyrząd pomiarowy danego typu spełnia wymagania, stanowiące podstawę zatwierdzenia typu. Jest to potwierdzenie $\mathrm{w}$ drodze decyzji, że typ przyrządu pomiarowego spełnia stawiane mu wymagania.

Świadectwo legalizacji - powinno być dołączone do przyrządu pomiarowego wprowadzonego do obrotu lub użytkowania.

Poniżej na rys. 2 przedstawiono w sposób graficzny podmioty upoważnione do legalizacji przyrządów pomiarowych i związane $\mathrm{z}$ nimi potwierdzenia metrologiczne.

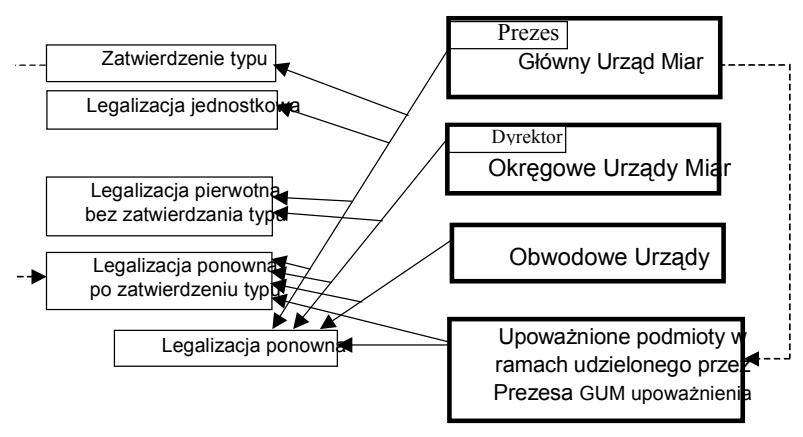

Rys. 2. Urzędy upoważnione do legalizacji w Polsce
Prawna kontrola metrologiczna przyrządów pomiarowych jest wykonywana przez organy administracji miar oraz podmioty upoważnione przez Prezesa GUM:

- zatwierdzenie typu i legalizację jednostkową dokonuje wyłącznie Prezes GUM

- legalizację pierwotną dla przyrządów nie wymagających zatwierdzenia typu wykonuje Prezes GUM oraz dyrektorzy Okręgowych Urzędów Miar

- legalizację pierwotną dla przyrządów posiadających zatwierdzenie typu oraz legalizację pierwotną dokonują wszystkie organy administracji oraz upoważnione podmioty $\mathrm{w}$ zakresie udzielonym im przez Prezesa GUM upoważnienia.

Dowodem wykonanej legalizacji jest świadectwo lub cecha legalizacji umieszczona na przyrządzie pomiarowym, świadcząca o dokonanej legalizacji.

Rodzaje dowodów legalizacji, okresy ważności legalizacji dla poszczególnych rodzajów przyrządów pomiarowych oraz terminy zgłaszania przyrządów pomiarowych do legalizacji ponownej po ocenie zgodności określone są w Rozporządzeniu Ministra Gospodarki z dnia 7 stycznia 2008r. w sprawie prawnej kontroli przyrządów pomiarowych Dz.U. nr 5 poz. 29, z późn. zm. [5].

\subsection{Kontrola i nadzór metrologiczny}

Za nieprzestrzeganie prawa o miarach [1] grożą sankcje karne przewidziane w ustawie.

Kompetentne organy odpowiedzialne za działania metrologii prawnej, lub za część tych działań, są zwykle nazywane służbami metrologii prawnej (organami administracji miar) i dokonują prawnej kontroli metrologiczne.

W Ustawie [1] w rozdziale 7 art 26 „Sankcje za naruszenie przepisów ustawy" zamieszczono sankcje prawne $\mathrm{i}$ finansowe dla tego, kto wbrew przepisom ustawy:

- wyraża wartości wielkości fizycznych w jednostkach miar innych niż legalne

- wprowadza do obrotu lub użycia, stosuje lub przechowuje w stanie gotowości do użycia przyrządy pomiarowe, podlegające prawnej kontroli metrologicznej, bez wymaganych dowodów jej kontroli lub nie spełniające wymagań

- użytkuje przyrządy pomiarowe niezgodnie z warunkami właściwego ich stosowania

- dokonuje legalizacji pierwotnej przyrządów pomiarowych bez wymaganego upoważnienia - świadomie utrudnia organom administracji miar wykonywanie ich zadań w zakresie sprawowania nadzoru podlega karze grzywny.

Zakres kontroli wykonywanej przez organy administracji państwowej przy sprawowaniu nadzoru nad wykonywaniem przepisów ustawy obejmuje:

- przestrzeganie obowiązku stosowania legalnych jednostek miar podczas użytkowania przyrządów pomiarowych, wykonywania pomiarów i wyrażania 
wartości wielkości fizycznych

- sprawdzanie spełniania wymagań przez przyrządy pomiarowe podlegające prawnej kontroli metrologicznej wprowadzone do obrotu lub użytkowania, stosowane albo przechowywane w stanie gotowości do użycia w dziedzinach, o których mowa w art 8 ust.1 ustawy [1]

- sprawdzanie posiadania przez przedmioty wprowadzające przyrządy pomiarowe do obrotu lub użytkowania oraz przez użytkowników przyrządów pomiarowych podlegających prawnej kontroli metrologicznej ważnych dowodów tej kontroli

- przestrzeganie spełnienia warunków właściwego stosowania przyrządów pomiarowych podlegających prawnej kontroli metrologicznej

- przestrzeganie obowiązku posiadania udzielonych upoważnień przez Prezesa Głównego Urzędu Miar do legalizacji pierwotnej lub legalizacji wtórnej przyrządów pomiarowych, oraz wydanych przez Prezesa Głównego Urzędu Miar zezwoleń na prowadzenie działalności gospodarczej w zakresie napraw lub instalacji oraz sprawdzania urządzeń rejestrujących stosowanych $\mathrm{w}$ transporcie drogowym

- spełnianie obowiązku utrzymania i udostępniania państwowych wzorców jednostek miar przez jednostki organizacyjne i laboratoria spoza administracji miar, będące właścicielami tych wzorców

- spełnianie warunków niezbędnych do wykonywania czynności na podstawie udzielonych upoważnień i zezwoleń

- przestrzeganie wymagań dotyczących paczkowania produktów i produkcji butelek markowych.

\section{Metrologia naukowa}

\subsection{Wprowadzenie}

Metrologia naukowa jest działem metrologii zajmujacym się utrzymaniem i rozwojem wzorców miar oraz wielkości z nimi związanych. Światowy system metrologi naukowej obejmuje szereg organizacji i porozumień międzynarodowych. W kolejnych punktach omówiono poszczególne elementy systemu a na rys. 3 są one zestawione w sposób uproszczony.

\subsection{Instytucje podstawowe}

Światowy system metrologi naukowej i przemysłowej opiera się na Konwencji Metrycznej [6], która jest traktatem międzypaństwowym podpisanym w Paryżu 20 maja $1875 \mathrm{r}$.

Polska przystapiła do Konwencji w roku 1925. Obecnie do konwencji należy 51 państw a 27 jest stowarzyszonych.

Postanowienia traktatu są realizowane $\mathrm{w}$ ramach trzech powołanych $\mathrm{w}$ nim organizacji międzynarodowych [9]. Są to:

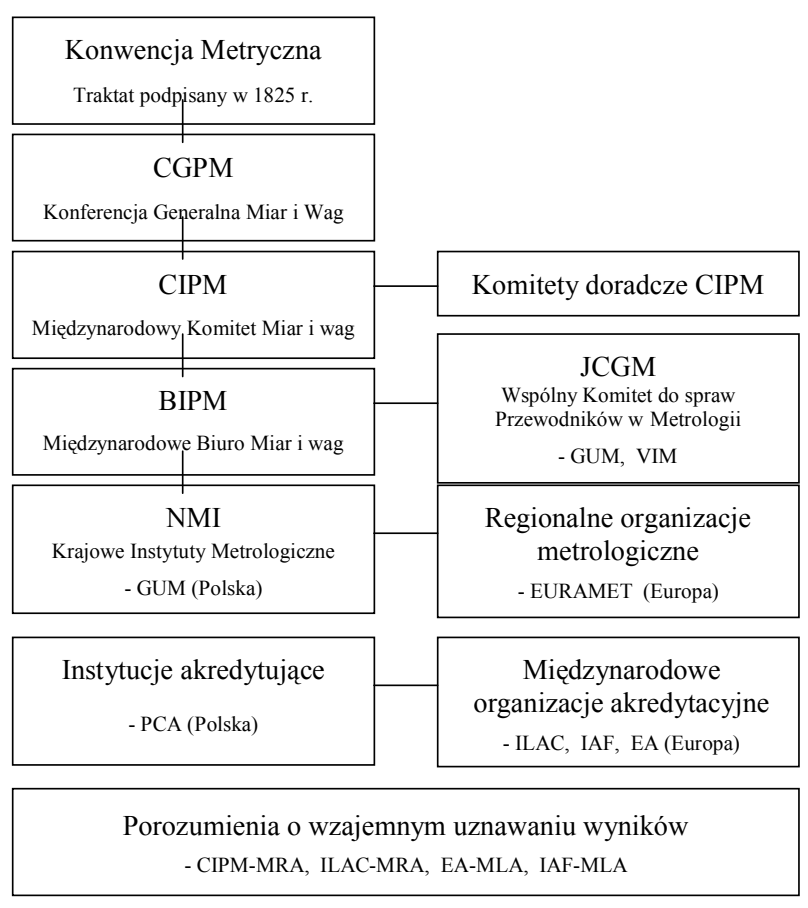

Rys. 3. Zestawienie najważniejszych instytucji i porozumień tworzących światowy system metrologi naukowej

- Generalna Konferencja Miar i Wag (CGPM),

- Międzynarodowy Komitet Miar i Wag (CIPM),

- Międzynarodowe Biuro Miar i Wag (BIPM).

Instytucje te organizują światowy systemem metrologiczny, kierują nim oraz uczestniczą w pracach naukowych i organizacyjnych związanych z jego rozwojem.

System metrologiczny obejmuje przede wszystkim tworzenie i utrzymywanie wzorców pomiarowych oraz wykonywanie porównań $\mathrm{z}$ wzorcami niższych rzędów.

W systemie tym kolejnym szczeblem są krajowe instytuty metrologiczne określane skrótem NMI (National Metrology Institutes), np.:

- USA NIST,

- Wielka Brytania NPL,

- Niemcy PTB,

- Polska GUM.

Instytuty krajowe zrzeszają się $\mathrm{w}$ organizacje regionalne, np. w Europie jest to European Association of National Metrology Institutes (EURAMET).

Do realizacji wybranych zagadnień powstały dodatkowe organizacje związane z BIPM, np.:

- Wspólny Komitet do Spraw Przewodników w Metrologii (JCGM),

- Wspólny Komitet do Spraw Spójności Pomiarowej w Medycynie (JCTLM).

Szczególną rolę w systemie metrologicznym odgrywają instytucje zajmujące się certyfikacją przyrządów pomiarowych i akredytacją laboratoriów pomiarowych. Na poziomie międzynarodowym tworzą one własne płaszczyzny współpracy, z których najważniejszymi o zasięgu światowym są International Laboratory Accreditation Cooperation (ILAC) oraz Interna- 
tional Accreditation Forum, Inc (IAF). Istnieją również organizacje regionalne tego typu - w Europie jest to European cooperation for Accreditation (EA).

Elementem systemu metrologicznego jest wzajemne uznawanie przez państwa wyników pomiarów. Uznawanie jest oparte o umowy międzynarodowe, z których najważniejsze, to:

- Porozumienie o wzajemnym uznawaniu państwowych wzorców jednostek miar oraz świadectw wzorcowania i świadectw pomiarów wydawanych przez krajowe instytucje metrologiczne (CIPM-MRA)

- Porozumienie o wzajemnym uznawaniu świadectw wzorcowania i pomiarów wydanych przez

laboratoria akredytowane (ILAC-MRA),

- Wielostronne Porozumienie (EA-MLA),

- Wielostronne Porozumienie o Wzajemnym Uznawaniu (IAF-MLA).

W utrzymaniu i rozwoju światowego systemu spójności pomiarowej uczestniczą również inne instytucje i organizacje, które nie są związane wyłącznie $\mathrm{z}$ metrologia, np.:

- Międzynarodowa Organizacja Normalizacyjna (ISO),

- Międzynarodowa Komisja Elektrotechniczna (IEC).

\subsubsection{Konwencja Metryczna}

Podpisanie Konwencji Metrycznej jest przełomowym wydarzeniem w rozwoju metrologii. Celem konwencji jest zapewnienie ogólnoświatowej jednolitości i spójności pomiarów.

Konwencja Metryczna jest traktatem międzypaństwowym zawierającym 14 artykułów zasadniczych i 22 artykuły aneksu. W części zasadniczej artykuł 1, powołuje do życia Międzynarodowe Biuro Miar i Wag (BIPM). Artykuł 3 konwencji ustala, że jej najwyższym organem jest Konferencja Generalna Miar i Wag (CGPM). Podlega jej Międzynarodowy Komitet Miar i Wag (CIPM), który z kolei jest organem nadrzędnym BIPM. Pozostałe artykuły konwencji precyzują ogólne cele i zasady działania powyższych instytucji.

\subsubsection{Konferencja Generalna Miar i Wag (CGPM)}

Konferencję tworzą delegaci rządów krajów sygnatariuszy Konferencji Metrycznej oraz obserwatorzy z krajów stowarzyszonych. Konferencja podejmuje obrady co najmniej raz na 6 lat $\mathrm{w}$ Paryżu. Dotychczas odbyło się 25 konferencji CGPM.

Konferencja otrzymuje raporty z prac Komitetu CIPM oraz podejmuje najważniejsze decyzje dotyczące Biura BIPM w tym związane $\mathrm{z}$ jego finansowaniem. Wspiera główne kierunki zmian w metrologi światowej w tym przede wszystkim zajmuje się rozwojem Międzynarodowego Systemu Jednostek SI i zatwierdzaniem zmian w ramach tego systemu.

Poniżej przedstawiono przykładowe tematy prac wybranych konferencji. a) Konferencja I - $1889 \mathrm{r}$.

- ustanowiono definicję metra jako odległość między dwoma kreskami na platynowo-irydowym wzorcu, złożonym w Międzynarodowym Biurze Miar w Sevres pod Paryżem;

- ustanowiono definicję i wzorzec kilograma (aktualny).

b) Konferencja X - $1954 \mathrm{r}$.

- ustanowiono sześć jednostek podstawowych: metr, kilogram, sekunda, amper, kandela,

stopień Kelvina (w 1967 roku na Konferencji XIII nazwę zmieniono na Kelvin);

- wprowadzono definicję jednostki ciśnienia - atmosfery fizycznej.

c) Konferencja XI - 1960 r.

- wprowadzono układ jednostek SI;

- zmieniono deficję metra opierając ją o parametry atomowe pierwiastka krypton.

d) Konferencja XIV - $1971 \mathrm{r}$.

- przyjęto siódmą jednostkę podstawową mol (jednostka ilości substancji);

- zatwierdzono nową nazwę jednostki ciśnienia paskal.

e) Konferencja XVII - 1983 r.

- ponownie zmieniono deficję metra opierając ją o prędkość światła w próżni.

f) Konferencja XXI - 1999 r.

- wprowadzono jako jednostkę pochodną katal (aktywność katalityczna).

3.2.3. Międzynarodowy Komitet Miar i Wag (CIPM) Międzynarodowy Komitet Miar i Wag (CIPM) stanowi 18 naukowców z różnych krajów członkowskich Konwencji Metrycznej. Członkowie CIPM są wybierani przez konferencję CGPM na okres między kolejnymi konferencjami. Kryteria wyboru członków obejmują kompetencje naukowe oraz wymaganie, aby w miarę możliwości reprezentowane były wszystkie państwa członkowskie oraz regiony geograficzne świata. Ze względu na rolę gospodarza Konwencji jedno miejsce w CIPM ma zawsze Francja. Obrady CIPM odbywają się raz w roku.

CIPM, z jednej strony jest organem nadrzędnym dla Międzynarodowego Biura Miar i Wag (BIPM). Z drugiej strony CIPM przygotowuje propozycje działań, które są zatwierdzane i przyjmowane do realizacji przez Konferencje CGPM. W celu wsparcia swoich prac CIPM powołuje Komitety Doradcze, które pracują w sposób ciągły. Obecnie pracuje dziesięć komitetów, np.:

- Komitet Doradczy Jednostek Miar,

- Komitet Doradczy Elektryczności i Magnetyzmu,

- Komitet Doradczy Długości.

3.2.4. Międzynarodowe Biuro Miar i Wag (BIPM) BIPM jest instytutem naukowym mieszczącym się $\mathrm{w}$ Sèvres na przedmieściach Paryża.

Misją BIPM jest zapewnienie funkcjonowania światowego systemu spójności pomiarowej. 
W jego laboratoriach prowadzone są prace badawcze związane $\mathrm{z}$ rozwojem systemu wzorców. Innym zadaniem laboratoriów jest utrzymywanie aktualnych wzorców najwyższego poziomu oraz wykonywanie wzorcowań wzorców, które w poszczególnych krajach członkowskich są wzorcami podstawowymi.

\subsubsection{Wspólny Komitet do spraw Przewodników w} Metrologii (JCGM)

W dziedzinie metrologii naukowej i przemysłowej funkcjonują dwa podstawowe dokumenty:

- „Przewodnik - wyrażanie niepewności pomiaru” określany skrótem GUM od angielskiej nazwy: „Guide to the expression of Uncertainty in Measurement", wydany w języku polskim przez Główny Urząd Miar (GUM) [7].

- „Międzynarodowy słownik podstawowych i ogólnych terminów metrologii" określany skrótem VIM od nazwy francuskiej: „Le Vocabulaire International des termes fondamentaux et generaux de Metrologie" [8].

Dokumenty te zostały opracowane przez Komitet ISO o nazwie Technical Advisory Group 4 (TAG 4). W 1997 powstał JCGM, który przejął odpowiedzialność za dalszy rozwój i promocję dokumentów.

Skupia on osiem organizacji międzynarodowych:

- International Bureau of Weights and Measures (BIPM),

- International Electrotechnical Commission (IEC),

- International Federation of Clinical Chemistry and Laboratory Medicine (IFCC),

- International Organization for Standardization (ISO),

- International Union of Pure and Applied Chemistry (IUPAC),

- International Union of Pure and Applied Physics (IUPAP),

- International Organization of Legal Metrology (OIML),

- International Laboratory Accreditation Cooperation (ILAC).

W ramach komitetu działaja dwie grupy robocze. Grupa JCGM/WG1 zajmuje się promocją przewodnika GUM oraz jego rozwojem. Przyjęto, że rozwój przewodnika będzie prowadzony $\mathrm{w}$ formie suplementów a nie w formie nowych wersji tekstu podstawowego.

Grupa robocza JCGM/WG2 zajmuje się promocją i rozwojem słownika VIM. Celem istnienia słownika jest utworzenie wspólnej platformy językowej i terminologicznej dla osób i instytucji zajmujących się metrologią $\mathrm{w}$ różnych dziedzinach nauki, przemysłu, medycyny, handlu, prawa i innych. Obecnie aktualna jest trzecia wersja słownika - VIM3.

3.2.6. Krajowe instytuty metrologiczne (NMI)

W poszczególnych krajach istnieje zwykle jeden instytut naukowy, będący kolejnym szczeblem w strukturze instytucji metrologii naukowej i przemysłowej. Zadania takiego instytutu obejmują zarówno utrzymywanie i przekazywanie wzorców jednostek miar jak i prace badawcze w dziedzinie metrologii.

W Polsce rolę takiego instytutu pełni Główny Urząd Miar (GUM).

Niektóre z tych instytutów ze względu na dotychczasowy dorobek oraz znaczny budżet są wiodącymi ośrodkami rozwoju metrologii w skali świata. Jako przykłady można wymienić:

- USA (National Institute of Standards and Technology - NIST)

- Wielka Brytania (The National Physical Laboratory - NPL)

- Niemcy (Physikalisch - Technische Bundesanstalt - PTB)

\subsubsection{Regionalne organizacje metrologiczne (EU- RAMET)}

Instytuty krajowe (NMI) zrzeszają się w regionalnych organizacjach obejmujących określone obszary świata. Obecnie funkcjonujące organizacje, na poszczególnych kontynentach to:

- Afryka (AFRIMETS),

- Azja rejonu Pacyfiku (APMP),

- Europa wschodnia i Azja (COOMET),

- rejon obu Ameryk (SIM),

- rejon Uni Europejskiej (EURAMET).

European Association of National Metrology Institutes (EURAMET) jest organizacją zrzeszającą krajowe instytuty metrologiczne (NMI) państw należących do Uni Eurpejskiej oraz do stowarzyszenia Europejskiego Stowarzyszenia Wolnego Handlu (EFTA). Członkiem organizacji jest również Komisja Europejska.

Głównym obszarem działalności EURAMET-u są badania naukowe $\mathrm{w}$ dziedzinie metrologii $\mathrm{w}$ tym programy badawcze finansowane przez Unię Europejska. Istotna $\mathrm{z}$ punktu widzenia praktyki jest działalność wydawnicza obejmująca między innymi przewodniki związane $\mathrm{z}$ pomiarami i wzorcowaniem przyrządów pomiarowych [11], [12].

Powyższe organizacje regionalne należą również do porozumienia CIPM-MRA (p.3.4.1). W ramach tego porozumienia organizacje te są ważnym ogniwem systemu wzajemnych porównań laboratoriów.

\subsection{Instytucje akredytujące}

Światowy system metrologiczny dotyczy wszystkich dziedzin, w których wykonywane są pomiary (badania naukowe, przemysł, handel i inne). Szczególną rolę w tym systemie pełnią instytucje akredytujące. Instytucje te zajmują się akredytacją laboratoriów działających w dziedzinie oceny zgodności czyli wzorcowania (kalibracji), badań, inspekcji oraz certyfikacji wyrobów, osób i systemów. 
Typowo w poszczególnych krajach jest instytucja upoważniona przez państwo, odpowiedzialna za akredytację na terenie kraju. W Polsce taką instytucją jest Polskie Centrum Akredytacji (PCA).

Krajowe instytucje akredytujące zrzeszają się w organizacjach międzynarodowych o zasięgu światowym jak ILAC, IAF oraz reginalnych jak np. EA w Europie.

\subsubsection{Międzynarodowa Organizacja Laboratoriów Akredytujących (ILAC)}

W 1997 roku powstała organizacja International Laboratory Accreditation Cooperation (ILAC) zrzeszająca instytucje zajmujące się akredytacją. Celem organizacji jest wymiana doświadczeń oraz promocja wzajemnego uznawania akredytowanych wyników badań i wzorcowań. Działania w ramach uznawania wyników są nakierowane $\mathrm{w}$ pierwszym rzędzie na wspieranie handlu światowego przez znoszenie jego technicznych barier. Taką barierą jest konieczność wielokrotnego wykonywania badań akredytacyjnych tych samych produktów. Wzajemne uznawanie wyników jest oparte o porozumienie ILAC-MRA (p.3.4.2).

\subsubsection{Międzynarodowe Forum Akredytacji (IAF)} International Accreditation Forum, Inc. (IAF) jest forum współpracy dla krajowych instytucji akredytujących, przedstawicieli jednostek akredytowanych oraz przedstawicieli przemysłu o zasięgu światowym. Celem działania organizacji jest udział w znoszeniu barier $\mathrm{w}$ handlu światowym. Środkiem działania jest promowanie sytuacji, w której akredytacje wydane $\mathrm{w}$ poszczególnych krajach są akceptowane w innych. Działania IAF są ściśle związane z polityką Światowej Organizacji Handlu (WTO). Międzynarodowe uznawanie akredytacji jest realizowane $w$ ramach porozumienia IAF-MLA (p.3.4.4).

\subsubsection{Regionalne organizacje akredytacyjne (EA)}

Regionalną organizacją zrzeszającą instytucje akredytujące w Europie jest EA - European co-operation for Accreditation. EA zrzesza instytucje reprezentujące państwa członkowskie i kandydujące do Uni Europejskiej oraz do EFTA (Europejskie Stowarzyszenie Wolnego Handlu).

EA działa w kierunku:

- ujednolicenia działań w zakresie oceny zgodności,

- prowadzenia systemu wzajemnych ocen laboratoriów,

- wzajemnego uznawania wyników (prowadzone w ramach porozumienia EA-MLA - p.3.4.3).

Polskie Centrum Akredytacji (PCA) jest członkiem EA oraz sygnatariuszem porozumienia EA-MLA. Wydany przez organizację Dokument EA-4/02 o wyrażaniu niepewności pomiaru przy wzorcowaniu [10] zawiera wytyczne obowiązujące instytucje działające w systemie akredytacji.

\subsection{Porozumienia o wzajemnym uznawaniu wyni- ków}

Ważnym elementem systemu metrologicznego jest wzajemne uznawanie państwowych wzorców miar oraz wyników pomiarów ujętych w postaci świadectw wzorcowań i pomiarów. Uznawanie jest oparte o umowy międzynarodowe o zasięgu światowym lub regionalnym. Najważniejsze porozumienia światowe, to CIPM-MRA oraz ILAC-MRA, a europejskie porozumienia regionalne, to EA-MLA i IAF-MLA.

\subsubsection{Porozumienie CIPM - MRA}

W październiku 1999 r. przedstawiciele 38 krajowych instytutów metrologicznych (NMI) podpisali przygotowane przez CIPM „Porozumienie o wzajemnym uznawaniu państwowych wzorców jednostek miar oraz świadectw wzorcowania i świadectw pomiarów wydawanych przez krajowe instytucje metrologiczne". Porozumienie jest określane skrótem CIPM-MRA od angielskiej nazwy 'Mutual Recognition Arrangement for national measurement standards and for calibration and measurement certificates issued by NMIs'. Obecnie porozumienie dotyczy większej liczby instytucji w tym regionalnych organizacji metrlogicznych, do których należy EURAMET. Dotyczy ono dwóch obszarów: porównywania wzorców pomiarowych poziomu krajowego oraz wzajemnego uznawania świadectw wzorcowania.

W Polsce sygnatariuszem porozumienia jest Główny Urząd Miar (GUM).

\subsubsection{Porozumienie ILAC - MRA}

ILAC-MRA - 'Porozumienie o wzajemnym uznawaniu świadectw wzorcowania i pomiarów wydanych przez laboratoria akredytowane'

W Polsce sygnatariuszem porozumienia jest PCA Polskie Centrum Akredytacji.

\subsubsection{Porozumienie EA - MLA}

Wielostronne Porozumienie EA Multilateral Agreement (EA-MLA) dotyczy wzajemnej akceptacji wyników pomiarowych uzyskiwanych przez jednostki akredytujące w Europie.

W Polsce sygnatariuszem porozumienia jest PCA Polskie Centrum Akredytacji.

\subsubsection{Porozumienie IAF - MLA}

IAF Multilateral Recognition Arrangement (IAFMLA) 'Wielostronne Porozumienie o Wzajemnym Uznawaniu' określa zasady równoważności programów akredytacyjnych oraz ich weryfikacji poprzez wzajemną ocenę zrzeszonych instytucji.

W Polsce sygnatariuszem porozumienia jest PCA Polskie Centrum Akredytacji.

\subsection{Krajowy system instytucji badawczych i wzorcujących}

Laboratoria pomiarowe działające w obszarze metrologii naukowej i przemysłowej można podzielić na badawcze i wzorcujące. Laboratoria badawcze realizują pomiary wynikające z dziedziny ich działania, a la- 
boratoria wzorcujące zajmują się wzorcowaniem przyrządów pomiarowych.

$\mathrm{Na}$ podstawie dobrowolnej decyzji oba rodzaje laboratoriów mogą podlegać akredytacji udzielonej przez instytucję funkcjonującą $\mathrm{w}$ ramach polskiego systemu prawnego i szerzej $\mathrm{w}$ ramach światowego systemu metrologicznego. W Polsce taką instytucja jest Polskie Centrum Akredytacji (PCA). Równoważna akredytacja może być udzielona również przez instytucje $\mathrm{z}$ innych krajów jeżeli funkcjonują $\mathrm{w}$ ramach porozumień o wzajemnym uznawaniu wyników, których sygnatariuszem jest również PCA.

Instytucją, która na szczeblu krajowym zajmuje się utrzymywaniem i przekazywaniem wzorców jednostek miar w ramach światowego systemu spójności pomiarowej jest Główny Urząd Miar (GUM).

Praktycznym celem funkcjonowania systemu instytucji metrologicznych, w tym laboratoriów wzorcujących jest zapewnienie, że uzyskiwane wyniki pomiarowe mają cechę spójności pomiarowej.

\subsubsection{Spójność pomiarowa}

Spójność pomiarowa jest właściwością wyniku pomiaru umożliwiająca wzajemne porównywanie uzyskanych wyników badań, niezależnie od miejsca i metody ich wykonania. Spójność pomiarową uzyskuje się przez porównanie wyniku pomiaru przez nieprzerwany, udokumentowany łańcuch porównań do wzorca państwowwego lub międzynarodowego.

\subsubsection{Główny Urzad Miar (GUM)}

Główny Urząd Miar jest urzędem administracji państwowej działającym na podstawie ustaw Prawo o miarach [1] oraz Prawo probiercze. GUM z jednej strony jest urzędem odpowiedzialnym za zagadnienia związane z zapewnieniem jednolitości miar w kraju co między innymi obejmuje utrzymywanie państwowych wzorców jednostek miar, a z drugiej ma status krajowego instytutu badawczego (NMI - p.3.2.6). W tej roli GUM reprezentuje Polskę w instytucjach wywodzących się z Konwencji Metrycznej (p.3.2.1).

GUM jest najwyższym, krajowym organem zarówno w obszarach metrologii naukowej i przemysłowej jak i metrologii prawnej.

\subsubsection{Polskie Centrum Akredytacji (PCA)}

PCA działa w oparciu o międzynarodowe normy dotyczące oceny zgodności - np. w zakresie laboratoriów badawczych i wzorcujących jest to norma PNEN ISO/IEC 17025 [13]. Działalność PCA jest też określona przez międzynarodowe porozumienia o wzajemnym uznawaniu wyników (p.3.4).

PCA udziela akredytacji laboratoriom oraz nadzoruje przestrzeganie warunków akredytacji podczas jej obowiązywania.

\subsubsection{Laboratoria wzorcujące}

Laboratoria wzorcujące są wyróżniona grupą laboratoriów, które realizują wzorcowanie przyrządów pomiarowych dla klientów zewnętrznych. Produktem laboratorium jest świadectwo wzorcowania.
Laboratorium musi w określony, systemowy sposób wykazać spójność pomiarową uzyskiwanych wyników z państwowymi wzorcami jednostek miar. Sposób działania laboratorium wzorcującego określa norma [13]. Jeżeli laboratorium działa $\mathrm{w}$ systemie akredytacji, to wynikające $\mathrm{z}$ tego wymagania są zamieszczone w dokumencie DAP-04 Polskiego Centrum Akredytacji [16].

\subsubsection{Laboratoria badawcze}

Laboratoria badawcze realizuja pomiary wynikajace $\mathrm{z}$ dziedziny ich działania. Typowym produktem laboratorium jest raport $\mathrm{z}$ badań. Podobnie jak w przypadku laboratoriów wzorcujących działania laboratorium badawczego określa norma [13]. Jeżeli laboratorium działa $\mathrm{w}$ systemie akredytacji, to wynikające $\mathrm{z}$ tego wymagania są zamieszczone w dokumencie DAB-07 Polskiego Centrum Akredytacji [17].

Laboratorium badawcze może prowadzić wzorcowania wewnętrzne aparatury pomiarowej na własne potrzeby. Posiada wówczas własne wzorce pomiarowe, które są okresowo wzorcowane w laboratoriach wzorcujących. Dla takich wzorcowań nie jest konieczna osobna akredytacja ale system tych wzorcowań musi spełniać warunki przedstawione w wytycznych PCA [15] oraz jest oceniany $w$ ramach okresowych kontroli.

Taka sytuacja ma np. miejsce w Laboratorium Instytutu Pojazdów Szynowych „TABOR”.

\section{Podsumowanie}

Aktualny stan prawny w Polsce wynika z Ustawy Prawo o Miarach [1] wraz z rozporządzeniami Ministra ds. Gospodarki [3] oraz Dyrektyw UE wdrożonych do prawa polskiego odpowiednimi ustawami i rozporządzeniami.

Prawna kontrola metrologiczna jest obowiązkowa dla przyrządów wymienionych w Ustawie i rozporządzeniach i obejmuje zatwierdzenie typu oraz legalizację. Pozostałe przyrządy mogą być wzorcowane. Istotna różnica między legalizacją a wzorcowaniem występuje w przypadku określania błędów przyrządu pomiarowego. W przypadku legalizacji błędy przyrządu pomiarowego odnoszą się do wartości tak zwanej działki legalizacyjnej przyrządu pomiarowego, natomiast przy wzorcowaniu błędy są odnoszone do działki elementarnej przyrządu pomiarowego. Istota sprawy polega na tym, że w przypadku niektórych przyrządów pomiarowych wartość działki elementarnej jest różna od elementarnej działki przyrządu pomiarowego.

W drugiej części przedstawiono instytucje i organizacje tworzace światowy system metrologii naukowej i przemysłowej. 


\section{Bibliografia}

[1] Ustawa z dnia 11 maja 2001r. Prawo o miarach (Dz.U. 2013 poz. 1069 z późn. zmianami),

[2] Ustawa z dnia 30 sierpnia 2002r. om systemie oceny zgodności (Dz.U. $2010 \mathrm{nr}$ 138, poz. 935 i nr 107 poz. 679, nr 114, poz. 760, z późn. zmianami),

[3] Rozporzadzenie Ministra Gospodarki z dnia 18 grudnia $2006 r$. w sprawie zasadniczych wymagań dla przyrzadów pomiarowych, Dz.U. $2007 \mathrm{nr}$ 3, poz. 27 (tzw. dyrektywa MID dyrektywa 2004/22/WE Parlamentu Europejskiego i Rady Unii Europejskiej),

[4] Rozporzadzenie Ministra Gospodarki z dnia 27 grudnia 2007r. w sprawie rodzajów przyrzqdów pomiarowych podlegajacych prawnej kontroli metrologicznej oraz zakresu tej kontroli (Dz.U. $\quad z$ 2008r. nr 3, poz. 13 z późn. zmianami),

[5] Rozporzadzenie Ministra Gospodarki z dnia 7 stycznia 2008r. w sprawie prawnej kontroli metrologicznej przyrzadów pomiarowych (DZ.U. nr5, poz. 29),

[6] The Metre Convention and Annexed Regulations. $B I P M$

[7] Wyrażanie niepewności pomiaru. Przewodnik.

[8] International vocabulary of metrology - Basic and general concepts and associated terms (VIM3), JCGM 2012
[9] Compendium of main rules and practices applicable to the BIPM. BIPM 07.2013

[10] Dokument EA-4/02. Wyrażanie niepewności pomiaru przy wzorcowaniu. EA - European co-operation for Accreditation, 1999

[11] Guidelines on the Calibration of Electromechanical Manometers. EURAMET cg-17, Version 2.0 (03/2011)

[12] Guidelines on the Calibration of Temperature Indicators and Simulators by Electrical Simulation and Measurement. EURAMET cg-11, Version 0.1 (07/2007)

[13] Norma PN-EN ISO/IEC 17025:2005 Ogólne wymagania dotyczqce kompetencji laboratoriów badawczych $i$ wzorcujacych

[14] Wzorcowanie aparatury pomiarowej. Janusz Piotrowski, Krystyna Kostyrko. Wydawnictwo Naukowe PWN, Warszawa 2012

[15] Polityka dotyczaca zapewnienia spójności pomiarowej. DA-06. PCA, Warszawa 2011

[16] Akredytacja laboratoriów wzorcujących. Wymagania szczególowe. DAP-04. PCA, Warszawa 2012

[17] Akredytacja laboratoriów badawczych. Wymagania szczególowe. DAB-07. PCA, Warszawa 2012 